Repartnering and childbearing after divorce: differences according to parental status and custodial arrangements

Author information:

Sofie Vanassche (corresponding author), PhD, post-doctoral researcher FWO at the Centre for Sociological Research (Family and Population Studies), KU Leuven, Belgium. Address: Parkstraat 45 - bus 3601, 3000 Leuven, Belgium. Email: sofie.vanassche@ soc.kuleuven.be

Martine Corijn, PhD, Research Center of the Flemish Government, Address: Boudewijnlaan 30, 1000 Brussels, Belgium. Email: martine.corijn@dar.vlaanderen.be

Koen Matthijs, PhD, professor at the Centre for Sociological Research (Family and Population Studies), KU Leuven, Belgium. Adress: Parkstraat 45 - bus 3601, 3000 Leuven, Belgium. Email: koen.matthijs@soc.kuleuven.be

Gray Swicegood, PhD, visiting professor at the Centre for Sociological Research (Family and Population Studies), KU Leuven, Belgium. Address: Parkstraat 45 - bus 3601, 3000 Leuven, Belgium. Email: Gray.Swicegood@ soc.kuleuven.be

Correspondence concerning this article should be addressed to

Sofie Vanassche

Centre for Sociological Research - KU Leuven

Parkstraat 45, post box 3601

3000 Leuven

Belgium

Email: sofie.vanassche@ soc.kuleuven.be

Tel: $+\underline{3216323050}$ 


\begin{abstract}
We use a stepfamily formation perspective to study two dimensions of the family life course following the dissolution of a first union. First, we examine how the presence of children from a prior union and the custody arrangements of those children influence the process of repartnering. In doing so, we extend the traditional explanations of union formation in terms of needs, attractiveness and opportunities by taking into account the parental status of the new partners and a detailed classification of the custody arrangement of the children. Next, we investigate the likelihood of childbearing within those post-separation unions with a particular emphasis on the prior parental status of both partners. By studying post-separation union formation and fertility behavior together we get a more complete depiction of stepfamily formation especially in their more complex forms. Our analyses are based on survey data for 2077 divorced men and 2384 divorced women collected in the Divorce in Flanders study. The results show that compared with other divorcees, full-time residential parents are the least likely to start a new union following separation and that parents are more likely to start a union with another parent than with a childless partner. Several of our results suggest that parenthood may not be a particularly attractive status on the partner market. Potential partners without children themselves appear especially reluctant to assume a (residential) stepparental role. In contrast with the results for union formation, it is not the custody arrangement of the child(ren) but parental status itself that predicts childbearing within higher order unions. Our findings are important from a policy perspective as they stress the consequences of gender-neutral childrearing patterns following divorce for the repartnering of women after separation.
\end{abstract}

\title{
Keywords
}

Post-divorce repartnering - Post-divorce childbearing - Parental status - Childrearing responsibilities - Joint custody 


\section{Repartnering and childbearing after divorce: differences according to parental status and custodial arrangements}

\section{Introduction}

Separation and divorce are increasingly common elements of individual biography in many western societies. Thus tracking the experiences that follow these break-ups has become crucial for a comprehensive understanding of contemporary family life. Our study focuses on two important life course transitions following the dissolution of a first union: 1) union formation (repartnering) and 2) childbearing. Although there is a considerable literature on both topics, it is rare that both are addressed in the same study. But these transitions together are the constituent elements of stepfamily formation. Using a stepfamily formation perspective to study post-divorce union formation and childbearing behavior carries theoretical and practical advantages that are reflected in our analytical framework and interpretation of results. The advantages derive in part from systematically considering the various ways children may influence their parents' behavior. The children of divorced women and men, the children of their potential new partners, and the potential children that they might have with their new partners can all be consequential for how post-divorce family life unfolds.

We build upon the analytical approach developed by Goldscheider and Sassler (2006) who were perhaps the first to explicitly 'integrate children into the study of union formation' and extend it in several ways. Our investigation of post-divorce union formation following separation takes into account the detailed parental status of the respondent and the parental status of her/his new partner. Using data on custody arrangements of the children of divorced adults, we also examine how the presence of children from a prior union and the level of childrearing responsibilities associated with those children influence the process of repartnering. By also considering the parental status of the new partners, our analyses provide new evidence on a range of factors (e.g. needs, attractiveness, opportunities and constraints) that have been hypothesized to operate in repartnering markets. 
In a second set of analyses, we investigate the likelihood of childbearing within those post-separation unions again taking into account the prior parental status of both partners. By studying post-separation union formation and fertility behavior together we get a more complete depiction of stepfamily formation especially in its more complex forms. When co-resident children from previous unions are present they can influence the motivations for and timing of fertility within the new unions. In these circumstances a new birth creates a more complex family form by introducing halfsibling relationships.

\section{Research context: the growing popularity of joint custody arrangements following parental divorce}

For many decades, the residential situation of children following a divorce reflected the logic of the male breadwinner system. Children lived almost exclusively full-time with their mother. Thus most studies of the impact of children on post-divorce union formation were only concerned with the distinction between adults with or without children and between parents with co-resident and noncoresident children (Beaujouan 2012; Ivanova, Kalmijn, and Uunk 2013; Sassler 2010). More recently, the shift towards a dual-earner family model and more gender-neutral childrearing patterns has reduced but not erased the gender asymmetry in custody arrangements among divorced mothers and fathers (Cancian et al. 2014). Since the 1990's, children of divorce are increasingly likely to live part-time with their mother and part-time with their father (Bjarnason and Arnarsson 2011). In a large number of Western countries (e.g. United States, Sweden, Norway, the Netherlands, Australia) the incidence of joint custody among children from the most recent divorce cohorts ranges between 10 and $30 \%$. As this type of arrangement becomes less exceptional, it assumes greater social relevance for children and their parents (Bjarnason and Arnarsson 2011; Cancian et al 2014).

Flanders (the Northern region of Belgium) is a particularly appropriate research context for the study of union formation and childbearing among divorced parents. Belgium has one of the highest divorce rates in Europe (Eurostat 2012). Moreover, the country has enacted progressive child custody 
legislation (Sodermans 2013). Joint legal custody was established in 1995 with the consequence that only in exceptional cases could judges decide to give parental rights exclusively to one of the biological parents. In 2006, joint physical custody was introduced as the preferred residential arrangement for children following parental divorce in cases where the parents do not agree on the custody arrangement. The percentages of children in joint custody range in Flanders from 10\% for children whose parents divorced between 1990 and 1995 to 33\% for children from divorces between 2006 and 2011 (Sodermans, Vanassche, and Matthijs 2013). When joint physical custody became a viable option, it was especially popular among highly educated, low-conflict ex-couples. But with the current wide-spread adoption of this arrangement, the profile of joint-custody parents has become more heterogeneous (Sodermans, Mattijs, and Swicegood 2013).

Our research brings focus to the consequences of Belgium's joint physical custody legislation. Under this arrangement, children are expected to reside with each of their separated parents for significant portions of time (a shared residential arrangement). The Divorce in Flanders survey data (Mortelmans et al. 2011) that we use for the empirical analyses allows us to measure the proportion of time that children are living with each parent. ${ }^{1}$ Although they should be closely related, it is actual time that the child co-resides with the parent rather than the legal custody status per se that is most likely to influence the divorced parent's repartnering and childbearing behavior. The underlying assumption is that the more time the child resides with a parent, the greater the childrearing responsibilities of that parent. The analytical literature review that follows indicates that the time and resources associated with those responsibilities have a key role in the theoretical expectations for the behavioral outcomes of interest.

\footnotetext{
${ }^{1}$ Parents with whom the children are co-residing some portion of the time are referred to as residential parents. If children reside exclusively with one parent, as was frequently the case for mothers in the past, then the parent has fulltime residential status. Parents with who the child stays infrequently or not at all are termed non-residential parents. The exact classification scheme that we use is laid out in detail in the methods section below.
} 


\section{Literature review}

\subsection{Parental status, custodial arrangements and union formation following separation}

Union formation involving children from previous unions leads to stepfamily formation. If only one of the partners brings children into the new union, the other partner becomes a stepparent. New unions with this structure may be referred to as 'simple' stepfamilies. If both partners bring children into the new union, they become stepparents to each other's children and a 'complex' stepfamily is formed. The defining feature of 'complex' stepfamilies is that they include children who vary in biological relatedness to the partners of the union: both partners assume the role of stepparents in these unions. A somewhat unique feature of our study is the focus on the parental status of both partners entering a new union thus lending insight into the factors that influence the likelihood of both simple (with one partner bringing children from a previous relation) and complex stepfamily formation (with both partners bringing children from a previous relation). In the simplest terms parental status depends on whether or not a person has a child, but for divorced parents it is also the residential arrangement of their children that will influence not only the likelihood of union formation but also the type of stepfamily that a new union will create.

The research literature suggests three mechanisms that could explain how repartnering behavior may be influenced by the parental status of the partners and custodial arrangements for the children: the divorcee's need for a partner, their attractiveness as potential partner and their opportunities to meet a new partner (Becker 1991; de Graaf and Kalmijn 2003; Goldscheider and Waite 1986; Ivanova et al. 2013; Oppenheimer 1988). The persistent finding that residential mothers are less likely to repartner compared to childless women and mothers with non-residential children had mainly been explained in terms of limited opportunities of single mothers compared to other women (Beaujouan 2012; Bumpass, Sweet, and Martin 1990; de Graaf and Kalmijn 2003; Ivanova et al. 2013; Koo, Suchindran, and Griffith 1984; Pasteels, Corijn, and Mortelmans, 2012; Teachman and Heckert 
1985). Empirical findings on the union formation of single fathers compared to other men have been less consistent, and thus different interpretations regarding the operation of the needs, attractiveness and opportunities of single fathers have been advanced (Bemhardt and Goldscheider 2002; De Graaf and Kalmijn 2003; Ivanova et al. 2013; Poortman 2007; Stewart, Manning, and Smock 2003).

Below, we extend prior research by incorporating distinctions involving the parental status of both partners along with a more detailed classification of the residential arrangement of any children from the prior union. The comparisons that are possible with this additional information may allow for a clearer view of the mechanisms that explain union formation according to parental status. Table 1 provides a summary of the key theoretical expectations in the research literature on how parental status and custody arrangements could shape post-divorce union formation. In the discussion below these influences are articulated with the summary table according to their designated row.

First, there are four different types of needs that are likely to affect the priorities of a separated person who is searching for a new partner. The first posits that childless men and women have a greater need for a new partner following a break-up in order to realize their fertility intentions (Beaujouan 2012; Lampard and Peggs 1999; Meggiolaro and Ongaro 2008). The need to become a parent should increase the likelihood that a childless person will repartner with a childless person since they would presumably share more similar childbearing goals (N1). A second type of need can originate in feelings of loneliness and the lack of social support: childless men and women and parents with parttime residential or non-residential children or adult children may feel more lonely compared to residential parents and therefore more in need of a new cohabiting partner (with or without children), providing social support (Lampard and Peggs 1999) (N1 \& N2). Third, there may be a need for a new partner to provide financial and caregiving support. This factor should be most salient for single parents with residential children. The need for financial support should direct such parents toward potential partners who are childless thus maximizing the additional resources that the new partner would bring $(N 1)$. On the other hand, repartnering with a parent who already has experience in this 
domain might more easily fulfill the need for childrearing support (N2). Finally, parents may give priority to other, emotional needs above their needs for support. If children do not have a favorable attitude about their mother's or father's new relationship then their parents may be reluctant to establish a stepfamily (Lampard \& Peggs 1999). Parents should be most susceptible to this influence if they co-reside with their child(ren). But parents themselves also may be reluctant to establish a stepfamily (N1), or to become a stepparent themselves in cases where the new partner would bring children from a previous union (N2).

In addition to shaping particular needs, parental status will also influence the attractiveness of men and women (how they are viewed as potential mates) on the partner market (Goldschneider and Sassler 2006). Potential partners without children may be more attracted to childless persons because they are more likely to share fertility goals $(A 1)$. Although this effect might operate through a mutual normative desire to become a parent, it could also be based on a shared preference for a childless lifestyle. They might also prefer a new partner who is also childless in order to avoid the stepparental role that would follow from beginning a union with a parent. Childrearing requires time, money and energy that can't be invested in the partnership, material goods or lifestyle preference and partners may anticipate problematic family functioning that reflects the incomplete institutionalization of relationships within the stepfamily (Goldscheider \& Sassler 2006; Sassler 2010; Sweeney 2010). The resulting reluctance of potential partners to form a stepfamily might be especially strong if it would involve a partner who had residential custody of a child(ren) (Beaujouan 2012; de Graaf and Kalmijn 2003; Ivanova et al. 2013; Stewart et al. 2003) (Al). However this reluctance might be diminished if the partner had shared as opposed to full custody of the child and the prospective stepchild would spend less time in the household (A1). Even potential partners with children themselves may prefer childless persons to avoid complex stepfamily formation and to maximize the resources that a new partner brings to the family (A2). However, men and women who have (residential) children themselves are not in a strong position to place much weight on the parental status of the other party. In terms of exchange processes, parents may 
therefore be more inclined or able to repartner with another parent than a childless partner $(A 2)$. On the other hand, in terms of partner homogamy, parents might also actually prefer another parent as partner (A2), just as childless persons prefer childless partners (A1) in part because they have more things in common. Finally the literature suggests that the attractiveness of parents to potential partners and the willingness to start a relationship with a parent may differ for men and women (South 1991). Traditional gender roles suggest that being a stepparent is more acceptable for women as they are more oriented towards caring for children (Goldschneider \& Sassler 2006). Women may be especially attracted to fathers who are actively involved in childrearing of nonresidential children, the so-called good-father effect (Stewart, Manning, \& Smock 2003). In times of more gender-neutral childrearing patterns with divorced fathers often being (part-time) residential parents, fathers may also increasingly prefer an experienced mother as new partner. This evolution might create a more gender-neutral good-parent effect with mothers and fathers preferring another parent as new partner $(A 2)$.

\section{[Table 1 about here]}

Third, the opportunities to meet potential partners are quite different for childless men and women, residential parents and non-residential parents. In general full-time residential parents have less time for social activities during which they might meet potential partners (Ivanova et al. 2013; Botterman, Sodermans, and Matthijs 2014; Wallerstein and Blakeslee 1989). This has been the primary explanation for why they are less likely to repartner. But parents with full or shared custody of their children do have opportunities to meet other parents through contacts at the school gate, community life, leisure activities of the children etc. Residential parents are more likely to meet potential partners who also have children via their child-oriented network $(O 2)$, while childless partners and nonresidential parents have more opportunities to meet potential partners without children during social activities or at work (O1) (De Graaf and Kalmijn 2003). 


\subsection{Parental status, custodial arrangements and childbearing following separation}

Parental status and custodial arrangements are also expected to influence the likelihood of having children within a new union. If children from previous unions co-reside, this translates into the birth of a half sibling, increasing the complexity of the stepfamily. The second aim of our study is to investigate how the likelihood of a birth within the first post-separation union differs according to the parental status of both partners and the residential arrangements of their children. In terms of stepfamily formation, the results will provide insights in the likelihood of the birth of a halfsibling in new families where children from previous unions co-reside.

The research literature offers two major hypotheses regarding childbearing within a new union (Kalmijn and Gelissen 2007). The parenthood hypothesis claims that (most) men and women want to become parents. Therefore, childless new couples should have the highest likelihood of childbearing and new couples where both partners are parents the lowest likelihood, independent of the custody arrangement of any children. $(P)$. In contrast, the commitment hypothesis stresses the importance of a shared biological child for building relational capital and for social confirmation of the union, independent of the presence of children from previous unions $(C)$. A proper test of either hypothesis requires that the individual partners' as well as the couple parity be considered. While a first shared child within a stepfamily may be viewed as a symbol of relationship commitment, it may also be the first biological child of one of the parents (Henz \& Thomson 2005).

The empirical evidence does not clearly favor one hypothesis over the other. Findings from several studies suggest that men and women with no or one child have the highest likelihood of childbearing within a new union or that couples are least likely to have a child after repartnering if both partners are already having children (Beaujouan 2011; Buber and Prskawetz 2000; Wineberg 1990). These findings have been interpreted as evidence against the commitment hypothesis, favoring the importance of (biological) parenthood. But other studies report little or no effect of children from a previous union on subsequent childbearing, consistent with the commitment hypothesis (Griffith, 
Koo, and Suchindran 1985; Jefferies, Berrington, and Diamond 2000; Vikat, Thomson, and Hoem 1999). Also the finding that that the probability of having a child is similar for childless couples and couples in which only one of the partners is a parent has been interpreted as evidence for the commitment hypothesis (Beaujouan \& Wiles-Portier 2011).

[Table 2 about here]

The number of children that partners had in previous unions might also influence fertility behavior in the new union. Parents who separate before they have had the desired number of children may wish an additional child in order to reach their own fertility goals (Beaujouan 2012). New partners might also be motivated to have a shared child by the desire for a sibling for a single child from one of their previous unions (Vikat et al. 1999). For parents, those couples with only one child would be expected to have the highest likelihood of additional childbearing (S). The empirical evidence for this so-called sibling hypothesis is mixed. Meggiolaro and Ongaro (2010) found no differences between women with one child and women with at least two in the risk of having a child following the dissolution of a marriage. Kalmijn and Gelissen (2007) found that having two prior children reduces the likelihood of a subsequent birth more than one prior child. Henz and Thomson (2005) used a step-parity specification to test the parenthood, commitment and sibling hypotheses for first and second shared births within stepfamilies. They found that, net of combined parity, couples with no or one shared child have higher birth risks than couples with two or more shared children. These findings support both the sibling and commitment hypotheses.

Finally, the custody arrangements of children from previous unions might be an important factor in the decision process on having (additional) children. According to the childrearing responsibility hypothesis (Vikat, Thomson, and Prskawetz 2004) the likelihood of having a child within a stepfamily depends on the level of responsibility required by children from previous unions. The assumption is that co-resident children require more responsibility and therefore will reduce the likelihood of a new child more than non-residential children would. Conversely, in case of non-residential or adult 
children, the birth of a shared child might be considered a more abrupt family transition for a couple than it would be if they already have residential children. Evidence has been found for both arguments (Kalmijn and Gelissen 2007; Vikat et al. 2004), but few studies have replicated these findings and we have no knowledge of studies of post-separation childbearing that assess the effect of part-time residential children separately.

Table 2 summarizes the expectations of the different hypotheses on the influence of parenthood on higher order union childbearing and provides a framework for the interpretation our findings. In this table, we made no distinction according to the parental status of the partner for the sibling and childrearing responsibilities hypotheses as we only have information on the number, age and custody arrangement of children from the key respondents, but not from their new partners. For the latter, we only know whether they had one or more children from a previous relationship or not. Therefore, a refined test of the sibling or childrearing hypothesis including the number of children of the new partner or the custody arrangement of these children is not possible in the present study.

\subsection{Control variables}

In modeling the relationships between parenthood and the residential arrangements of children from a previous union and post-separation union formation and childbearing, it is important to control for potentially confounding factors. There have been important changes in the composition of the population of divorced men and women in terms of their mean age at marriage and at divorce, the duration of their marriage and parenthood (Corijn 2013a). The growing acceptance of divorce has been accompanied by an increased tolerance for and a widened access to post-separation partners and family life (Corijn 2013b; Halman, Sieben, and van Zundert 2011). Moreover, we know that in Belgium ex-partners with children in a joint custody arrangement are, on average, more recently divorced than those with children in full-time mother custody because the prevalence of joint physical custody has been increasing over time (Sodermans et al. 2013). Thus it is important that we control for the year of the separation. 
Age is strongly related to both being a parent, the number of children one has, and the likelihood of repartnering and childbearing following a union dissolution (Beaujouan 2012; Jefferies et al. 2000; Pasteels et al. 2012). Men and women who separate or divorce at a (very) young age have a greater motivation to repartner, are more attractive as potential partners and have more opportunities to meet new partners as compared to those whose partnership ends at an older age. Women over age 40 also have a low probability of giving birth. In addition, children in joint custody are on average younger than children in sole mother or father custody (Sodermans et al. 2013), and the age of children tends to be related to the age of the mother and the father as well. Thus we control for the age of the divorcee and the age of the new partner in the childbearing analyses.

Third, educational attainment affects the probability of post-separation repartnering (Dykstra and Poortman 2010; Sweeney 1997). In Flanders, lower educated, divorced men are less likely to find a new partner, but there is no relationship between education and repartnering for divorced women (Pasteels et al. 2012). In addition, ex-partners with children in joint custody tend to be more highly educated than ex-partners who have other types of custody arrangements (Gunnoe and Braver 2001; Sodermans et al. 2013).

Finally, the number of children and their age at the time their parents separate or divorce are related to whether and when their parents form new unions. Divorced parents with more and younger children are less likely to repartner (Ivanova et al. 2013; Meggiolaro and Ongaro 2008; Poortman 2007). Because the age and number of children is also related to the custody arrangement (Cancian et al. 2014; Sodermans et al. 2013), it is important to control for both variables when estimating the effect of custody arrangements on union formation. 


\section{Data and methods}

\subsection{Data and research sample}

We use the data from the Divorce in Flanders (DiF) survey (Mortelmans et al. 2011). DiF is a largescale survey that focuses on the causes, consequences and policy implications of divorce in Flanders (Belgium). The survey design incorporates both married and divorced couples who are questioned about the initiation and development of their past and current partnerships, their relationship with their children, their well-being, their social networks and their employment and income situation. In the case of divorced couples, both (ex-)partners, one of their children and one of their parents were interviewed as well as their partners from any new union. A sample of marriages conducted between 1971 and 2008 was drawn from the Belgian National Register. Marriages had to meet the following selection criteria to become the so-called reference marriages: 1) the partners are of a different sex,

2) the marriage is the first for both partners, 3) both partners were between 18 and 40 years old at the time of their first marriage, 4) both partners have the Belgian nationality from birth, 5) both partners are domiciled in the Flemish Region at the times of the marriage and of the sampling, 6) both partners are still alive, and 7) both partners were not divorced more than once. The sample is proportional according to the marriage year, but disproportional according to the outcome of the marriage. One third of the reference marriages $(n=2502)$ were still intact in 2009 and two thirds $(n=6004)$ were dissolved.

The two partners from each reference marriage were invited to participate and were questioned by means of Computer Assisted Personal Interviewing (CAPI) between September 2009 and December 2010. Within that period, 4659 ex-partners from dissolved reference marriages were questioned, including 1134 marriages from which both ex-partners participated in the study. This corresponds with a response of $39 \%$ of all selected, dissolved marriages. Relative to all contacted, dissolved marriages, the response rate equals $43 \%$. 
In discussing the selectivity within the sample, we focus on the response rate relative to the gross sample of all selected marriages. As the sample was drawn from the National Register, we have information on the sex, year of birth, and marriage year of all contacted persons (Pasteels et al. 2010). Within the dissolved marriages, especially people from the most recent marriage cohort (2006-2008) are underrepresented ( $\pm 25 \%$ versus $\pm 35 \%$ within all other cohorts). The response rate for divorced women $(41 \%)$ is slightly higher than for divorced men $(36 \%)$. The response rates for divorced men and women born between 1930 and $1939( \pm 20 \%)$ and between 1980 and $1989( \pm 30 \%)$ are much smaller than for the (large majority of) persons born between 1940 and $1979( \pm 40 \%)$. Next, we have certain information on the people that not participated in the study in case the (ex-)partner participated. Within the group of divorced men and women, the respondents that participated were more often highly educated (33\%) compared to the selected respondents that not participated (25\%). Divorced respondents that non participated in the study were also more frequently living together with a new partner (70\%) compared to respondents that participated in the study $(60 \%)$. In-depth studies also demonstrated that residential and involved (divorced) parents more often participated in the study compared to non-residential and less involved parents (Bastait et al. 2015; Sodermans 2013).

During the interview with the ex-partners, the complete pre- and post-separation partner and fertility trajectory was assessed in terms of timing, type, duration and stability. If the partners from a dissolved reference marriage had at least one common (biological or adoptive) child, a random target child was selected for more detailed information $(\mathrm{n}=2637)$. Priority was given to a child who was 10 years and older and lived with at least one of the parents, preferably the first interviewed parent ( $\mathrm{n}=1696$ or 64\%). The next preference was given to a child of 18 years and older who did not live with his/her parent $(n=743$ or $28 \%)$. The third highest priority was given to a child younger than 10 who was living with at least one parent, preferably the first interviewed parent ( $\mathrm{n}=185$ or $7 \%$ ). If not, a child younger than 18 who did not reside with at least one parent was selected ( $\mathrm{n}=13$ or $<1 \%)$. The parents were questioned about the target child, including the nature of their custody arrangements. 
In order to model post-separation union formation, we selected the divorced men and women with valid information on their date of separation. This resulted in a research sample of 2077 divorced men and 2384 divorced women. It is important to stress that although our study only includes (ever) divorced persons, we analyze the likelihood of union formation in the period following the date of the respondent's separation because some months or even years may pass between the separation and the actual legal divorce. Many new partnerships may begin within that period. In restricting the analyses to residential unions, we have decided not to distinguish between unmarried cohabitation and remarriage. 1288 men and 1316 women started a union (unmarried cohabitation or remarriage) within the first ten years following separation: 628 men and 620 women with a partner without children, and 660 men and 696 women with a partner with at least one child.

The likelihood of childbearing within the first new union is analyzed within the subsample of men and women who started a union within the first ten years following separation. Fifty men and fortyeight women were excluded because of invalid or inconsistent information on the end of the first union. Four of the excluded men and three of the excluded women reported having a child within that union. Of the 1238 men and 1268 women in the final subsample, 348 men and 357 women gave birth to a child within the first ten years following the start of the union.

\subsection{Measurement: independent and control variables}

The main independent variable is the parental status of the divorcees. This variable distinguishes between parents and childless divorcees and among the parents, whether the parent has minor children younger than age 18 or not. Within the group of parents with minor children, a further distinction is made between parents with full-time residential children (>75\% of the time on a monthly basis), parents with part-time residential children (between 25 and $75 \%$ of time), parents with non-residential children $(<25 \%$ of time) and parents with minor children in other (often flexible) arrangements. Parents whose children were all older than age 18 are also distinguished separately in the analysis. Thus our key independent variable combines information on parental status and the custody 
arrangements and age of children into six categories: 1) no children, 2) full-time residential, minor child(ren) 3) part-time residential, minor child(ren), 4) non-residential, minor child(ren), 5) minor children in other arrangement and 6) adult children only. This variable is time-varying, incorporating the changes in the custody arrangement of the child and the increasing age of all children. The value for persons without children at the time of separation is constant over time. The information on the custody arrangement refers to the target child, while the age of the youngest child from the reference marriage is used to measure the presence of minor children ${ }^{2}$.

In modeling the likelihood of childbearing within the first union, we also include the parental status of the new partner. We include this information in two ways. First, we construct a variable that distinguishes between a partner with at least one child from a previous union and a childless partner. Second, we combine the parental status of both partners, distinguishing between unions with 1) both partners having no children, 2) respondent having children, but partner does not, 3) partner having children, but respondent not, and 4) both partners having children.

We include the year of separation as a metric variable, centered around its mean. The respondent's age at the time of separation is coded into three categories: younger than 30 years, between 30 and 39 years, and 40 years or older. In the models of childbearing within the first post-separation union, the age of the partner at the start of the new union is categorized in the same way. Respondent's education is coded into three categories: lower educated (lower secondary school or less), average educated (higher secondary school) and higher educated (post-secondary or higher education). The

\footnotetext{
${ }^{2}$ It is important to note that the complete history of the custody arrangement following separation is only known for the selected target child (see data section). The distinction between full-time, part-time and non-residential (minor) child(ren) is hence based upon the information of the target child and does not allow for differences in custody arrangement amongst siblings. To have an idea about the impact of this limited operationalization, we compared the rough information on the custody arrangement of brothers and sisters born within the same dissolved marriage at the time of the interview (for children still residing in the parental home at that time) or before leaving the parental home (for children who had already left the parental home at that time). This comparison indicates that $14 \%$ of the common children of ex-partners have a different custody arrangement.
} 
age of the respondent's youngest child at the time of separation and the number of children from their dissolved marriage are included as metric variables, centered around their mean.

Table 3 contains the descriptive statistics for the independent variables for the full research sample with all divorced men and women, and for the subsample of men and women who started a union within the first ten years following separation. Statistics for the time-varying parenthood variable are limited to those reported at the time of separation for the full sample, and those reported at the start of the first union for the subsample.

[Table 3 about here]

\subsection{Methods}

We use a multinomial hazard model to estimate the likelihood of remaining single, union formation with a childless partner and union formation with a parent. The analysis of union formation is limited to the first ten years following separation for several reasons. First, previous studies suggest that Flemish men and women who repartner after separation, do so rather quickly (Defever and Mortelmans 2011; Pasteels et al. 2012). Second, longer periods of risk are only available for older separation cohorts. Third, the proportion of men and women having minor children from the dissolved marriage at home decreases as time since separation elapses. Additional analyses excluding respondents who initiated their first union with a partner who they already met before their separation did not yield different results.

To model the likelihood of childbearing within the first union following separation, we apply discretetime event history analyses. Analogous to union formation, the birth of a child within a new union occurs relatively quickly after the start of that union (Buber and Prskawetz 2000; Wineberg 1990). Preliminary analysis of the DiF data shows that more than $90 \%$ of the children born after a separation were born within the first new union following separation. We therefore have chosen to model the likelihood of a birth within the first ten years of the first union. These criteria imply that respondents 
disappear from the population at risk by either giving birth or by ending the first post-separation union, whichever comes first, or after the tenth year following the start of the union.

Because the time-varying parental status (see below) can only be reconstructed in years, we model the likelihood of both events on a yearly basis. As we have a limited number of discrete time periods (10 one year intervals), we apply a general specification of both baseline hazard functions and use the first year following separation as reference category for the models of union formation, and the first year following the start of the first union for the models of childbearing. Both events are modelled for men and women separately so that any gender differences in the effects of the parental status and custodial arrangements will be apparent.

\section{Results}

\subsection{Parental status, custodial arrangements and the likelihood of union formation following}

\section{separation}

Table 4 contains the results from the multinomial hazard models on union formation with a partner with or without children. The baseline hazard function (coefficients not included in table) shows a linear decrease in the likelihood of union formation over time. In others words, union formation occurs rather quickly following separation.

We see that only men and women with full-time residential children have a lower likelihood of union formation with a childless partner (versus no union formation) compared to childless persons. In contrast with most other groups of parents with minor children, they do not have a higher likelihood than childless divorcees of partnering with a parent (versus no union formation). Together, these findings demonstrate a lower likelihood of union formation (in general) for parents with full-time residential, minor children ${ }^{3}$. Explanations for these patterns (see Table 1) can be found in the

\footnotetext{
${ }^{3}$ Additional analyses in which the overall likelihood of union formation was modeled (independent of the parental status of the new partner) showed indeed that only full-time residential parents have a lower likelihood of union formation compared to childless divorcees. This finding holds for men and women.
} 
attractiveness to potential partners without children (A1), and the limited time of full-time residential parents for social activities during which they meet potential partners without children (O1).

Parents with part-time and non-residential, minor children or minor children in another arrangement do not differ from childless divorcees in their likelihood of forming a union with a childless partner (versus staying single). Men and women with non-residential minor children or other arrangements have a higher likelihood of repartnering a parent (versus staying single) than childless divorcees. The likelihood difference between having full-time and part-time minor children is more pronounced for women than for men. For almost all parents with minor children, we see that the likelihood of union formation with a parent (versus with a childless partner) is higher than for childless persons. The finding of no differences according to the residential arrangement of the children suggests an interpretation involving exchange processes or partner homogamy (A2) rather than the opportunities to meet potential partners with or without children or parenthood being an attractive characteristic to all potential partners, including those without children. Finally, parents of adult children are not significantly different from childless men and women in any of our models of union formation ${ }^{4}$.

[Table 4 about here]

For both men and women, the older the youngest child is at the time of separation, the higher the likelihood that the new union is with a parent rather than with a childless partner. But the age of the youngest child is not related to the likelihood of union formation versus staying single. Nor is the number of children from the dissolved marriage related to the likelihood that male divorcees repartner. But among women, more children slightly decrease the likelihood of starting a union with

\footnotetext{
${ }^{4}$ The profile of post-divorce families with children in sole and joint custody has changed over time in Flanders. Therefore, we tested for interaction effects between the year of divorce and the parental status of the divorcees to see if the relationship between specific custody arrangements among parents and post-divorce union formation has changed over time. The inclusion of this interaction term did not significantly improve the model nor was the estimated coefficient for the interaction term statistically significant.
} 
a childless new partner (versus remaining single), while modestly increasing the chances that the new union will be with another parent.

For men and women, the likelihood of repartnering a childless partner or a parent is higher for more recent divorces. Men and women younger than age 30 have a higher likelihood of starting a new union with a childless partner (versus remaining single) than older men and women. When older men do repartner they are much more likely to do so with a mother than with a childless woman. The oldest age category of women has much lower likelihoods of repartnering with either parents or childless persons compared to younger women. Overall, the findings suggest that age has a stronger impact on the likelihood of union formation for women than for men.

Education is related to the likelihood of union formation only among men. Lower educated men are less likely to start a union with a childless person (versus no union formation), while higher educated men are more likely to start a union with a childless person (versus no union formation). The likelihood of union formation with a parent (versus no union formation) is not differentiated according to the educational level of men, but lower educated men are more likely to start a union with a parent (versus with a childless partner) compared to higher educated men.

\subsection{Parental status, custodial arrangements and the likelihood of a birth within the first union}

\section{following separation}

Table 5 presents the results from the event history models of the likelihood of a first birth within the first union following separation. Two models are estimated for men and women. In the first model the parental status of the new partner is included as a control variable; in the second model the parental status at the couple level is included. The results for the baseline hazard function (coefficients not included in table) show that the likelihood of a birth decreases with union duration from the first year 
onwards among women, while among men this likelihood is equal within the first five years and decreases gradually afterwards.

The first model indicates that there are no significant differences between parents with minor children according to the residential arrangement of their children. The likelihood of having a child within the new union is clearly highest for divorced men and women without children. Similar, the likelihood of a birth is much lower in cases where the new partner already has children. The second model shows that couples in which both partners have children from a previous union are the least likely to have an additional child. Moreover in cases where only one of the partners has prior children, the likelihood of having a shared child is lower, especially in the women's model. These results are consistent with the parenthood hypothesis $(\mathrm{P})$.

[Table 5 about here]

For women, the age of the youngest child at time of separation is negatively related to the likelihood of a new birth. The number of children from the dissolved marriage is not related to the likelihood of a new birth for either men or women. Additional analyses (not shown) in which differences between divorced parents with one child versus those with two or more children were tested did not show that further childbearing is more frequent among men and women with only one child from the dissolved marriage.

The likelihood of childbearing within the new union is higher among men and women from more recent divorces. The effect of age at the start of the new union is more pronounced among women than among men: younger women have a higher likelihood of childbearing, while women of 40 years or older have a very low likelihood. Conversely, the age of the new partner at the start of the new union is more influential among men than among women.

Finally, for men we find no educational differences, but among women, we find that higher educated divorced women have higher birth probabilities compared to women with less education. 


\section{Discussion}

In this study, we explored the association between parental status, custodial arrangements of children following divorce and the likelihood of union formation following separation and childbearing within that union. If children from previous unions are involved, these events relate to stepfamily formation and the birth of a halfsibling. When a parent repartners with another parent and those children live with them in the same household, the children acquire one or more coresidential stepsiblings.

We report evidence that the residential childrearing responsibilities are more important for postseparation repartnering than parental status itself. These findings are in line with the results of Beaujouan (2012). Only full-time residential, minor children decrease the likelihood of starting a new union for men and women. The hypothesized higher needs of single, full-time residential parents for financial and childrearing support do not translate into more frequent union formation amongst our Flemish sample. The explanation for the lower likelihood of starting a new union of full-time residential parents would appear to lie in the attractiveness or opportunity domain. Reluctance to assume a full-time residential stepparent should be independent of the parental status of this stepparent and therefore is not likely to explain why we only find a lower likelihood of union formation of full-time residential parents with childless partners. A more plausible explanation is that full-time residential parenthood substantially constrains social activities and thereby decreases opportunities to meet new partners, especially new partners without children (Beaujouan 2012; Wallerstein and Blakeslee 1989). Another compatible explanation gives agency to the prospective partners who may find the role of full-time, residential stepparent to be unattractive especially if they have no children themselves.

Secondly, we find that parents are more likely to start a union with another parent than with a childless partner. Thus simple stepfamily formation turns out to be less likely than complex stepfamily formations that create new stepsibling relationships. But what explains the fact that divorced parents more often repartner with other parents? Opportunities to meet other parents (e.g. at the school 
grounds, at football matches, theater performances or other leisure activities of the children) is certainly a plausible mechanism for parents with residential children, but it does not explain why parents with non-residential children are also more likely to form a union with another parent. For all parents, a mechanism involving the exchange of partner characteristics may be at work: Parents may be more attractive to other parents than they are to childless men and women. Several of our results suggest that parenthood is not a particularly attractive status on the partner market. One indication is that lower educated men, who experience more difficulties on the partner market, repartner more frequently with a parent than do higher educated men. A second indication is that only full-time nonresidential parents with minor children (or with children in other, often flexible arrangements) have a higher likelihood of repartnering a parent than childless men and women. In other words, the socalled 'good-parent' effect only holds if the children are not living full-time with the parent and is only applicable for union formation with another parent. If potential partners are indeed less skeptical about non-residential stepchildren than residential stepchildren, this provides additional evidence that residential arrangements are more important for union formation than parenthood itself.

Third, childless men and women are especially likely to have a shared child within a new postseparation union. In contrast with the findings on union formation, it is not the residential arrangement of the child(ren) but rather the parental status itself that predicts childbearing within higher order unions. Thus common fertility goals may be part of the reason why childless divorcees typically form their next union with another childless person. Our results suggest that the desire to have one's own biological child is perhaps the key driver of childbearing within higher order unions, rather than sharing a child with the new partner. As suggested by Beaujouan \& Wiles-Portier (2011), it would be interesting to study post-divorce formation, partner choice and child-bearing as interdependent events in future studies. In addition, the fact that couples where only one partner is a parent have a lower likelihood of having a child together than couples with no children at all, might reflect a certain reluctance to add to the complexity of the new family. In terms of stepfamily formation, the birth of child is less likely if it would create half-sibling relationships and is the least likely if these half sibling 
relationships would add up to existing stepsibling relationships. Thus the birth of a shared child is lower in case it creates a new type of sibling relationships, varying in biological relatedness to both parents.

The sampling design and questionnaire content of the Divorce in Flanders study raises several issues. First, detailed information on (the changes in) the custody arrangement is only available for the selected target child. Thus parental status is measured by the custody arrangement of that child, but there might be a different custody arrangement for their (biological) brothers and sisters. An exploratory analysis of differences in the custody arrangement between siblings shows that these situations are relatively rare. Second, the number of divorced fathers with full-time custody of their children is small ( $\mathrm{n}=166 \& 71)$, so the results for this group have reduced statistical power. Third, the design of the study limited the ever-divorced subsample to those with only one divorce. Given that the presence of stepchildren is related to higher order union dissolution (Henz \& Thomson 2005), some additional selectivity is thereby introduced into our sample of separated parents next to the selective non-response discussed in the data section. Finally, we note that although our emphasis has been on the effects of the parental status on post-separation family transitions, some reverse causality chain might be involved in this relationship. For example, the repartnering of a parent might result in their adapting the custody arrangement to the new family configuration. An exploration of this bidirectionality is beyond the scope of this research, but deserves attention in future studies.

We conclude by noting that our results are important from a policy perspective in large part, because there is an important gender dimension in our findings. Before joint custody became the normative standard, childrearing responsibilities following divorce were almost completely carried out by mothers, which impeded new unions. Recent changes in Belgian divorce law and practice, largely a reflection of the normative climate, have encouraged more divorced parents to choose a shared physical custody arrangement with its implicitly greater sharing childrearing responsibilities. This trend has created more child-free time for separated mothers, which facilitates meeting new partners. 
Moreover, joint custody implies more time and privacy for a romantic relationship (Crosbie-Burnett 1989). This part-time, private time for the new union is likely to be more attractive to potential partners than full-time residential stepparenthood. Therefore, if the current trend of increasing joint custody persists, we might expect a further increase in the proportion of women repartnering after separation. In addition, our results show part-time residential fathers are as likely to repartner as nonresidential fathers. We know from previous studies that divorced men and women who repartner have better economic and emotional well-being than divorced men and women without a new partner (Fokkema 2001; Fokkema and Dykstra 2002; Jansen, Mortelmans, and Snoeckx 2009; Sweeney 2010). Therefore, the increasing incidence of joint custody may increase the well-being of divorced mothers, without reducing the well-being of divorced fathers. This possibility should inform the evaluation of specific custody arrangements following parental union dissolution and policy measures seeking to promote specific arrangements. Additional benefits of shared residence (e.g. a close relationship with both parents) should also be weighted against the potential disadvantages of joint custody reported in the literature (e.g. frequent switching houses, opportunities for parental conflict, discontinuities in parenting styles) and the challenges involved in stepfamily formation. Growing numbers of children in joint custody arrangements imply that children increasingly will have a parttime residential stepfather, often in combination with a part-time residential stepmother. Children, parents and stepparents often need time to adapt to these new family configurations (Jeynes 2006). In terms of family policy, the growing trend of stepfamily configurations contrasts strongly with the very limited juridical framework concerning stepfamily relationships in most western countries. The social and juridical challenges related to these complex relationships undoubtedly deserve greater attention from policy makers in the near future.

In summary, the main contributions of our study of post-separation family life are threefold. First, we provide additional empirical evidence on the impact of parenthood on union formation and childbearing following separation. Second, our results demonstrate the importance of distinguishing between parents with full-time and part-time residential children in studying the impact of parenthood 
on union formation. Third, we demonstrate the value of incorporating characteristics of the new partner into the study of post-divorce union formation. In the case of separated parents, these characteristics determine the nature of stepfamily formation. Here we focused on the parental status of the partner, but the broader demographic and socio-economic profile of these partners or stepparents need further exploration. 


\section{References}

Bastaits, K., Pasteels, I., Ponnet, K. \& Mortelmans, D. (2015). Adult non-response bias from a child perspective. Using child reports to estimate father's non-response. Social Science Research, 49, 3141.

Beaujouan, E. \& Wiles-Portier, E. (2011). Second-union fertility in France: partners' age and other factors. Population, 66(2), 239-273.

Beaujouan, E. (2012). Repartnering in France: The role of gender, age and past fertility. Advances in life course research, 17, 69-80.

Becker, G. S. (1991). A treatise on the family. Cambridge: Harvard University Press.

Bemhardt, E. \& Goldscheider F. K. (2002). Children and union formation in Sweden. European Sociological Review, 18(3), 289-299.

Bjarnason, T. \& Arnarsson, A. M. (2011). Joint physical custody and communication with parents: a cross-national study of children in 36 western countries. Journal of Comparative Family Studies, 42(6), 871-890.

Botterman, S., Sodermans, A.K. \& Matthijs, K. (2014). The social life of divorced parents. Do custody arrangements make a difference in divorced parents' social participation and contacts?, Leisure Studies, DOI: 10.1080/02614367.2014.938768

Buber, I. \& Prskawetz, A. (2000). Fertility in second unions in Austria: Findings from the Austrian FFS. Demographic Research, 3(2).

Bumpass, L., Sweet, J. \& Castro Martin, T. (1990). Changing patterns of remarriage. Journal of Marriage and Family, 52(3), 747-756.

Cancian, M. \& Meyer, D. R. \& Brown, P. R. \& Cook, S. T. (2014). Who gets custody now? Dramatic changes in children's living arrangements after divorce. Demography, 51(4),1381-1396. 
Corijn, M. (2013a). Veranderingen in de burgerlijke staat doorheen de levensloop (Changes in the civil status in the life course). In M. Corijn \& C. Van Peer (eds.). Gezinstransities in Vlaanderen (Family transitions in Flanders). Brussel: Studiedienst van de Vlaamse Regering, SVR-studie 2, 2136.

Corijn, M. (2013b). Gezinsvorming en -ontbinding sinds 2000: veranderingen in gedrag en in opvattingen. (Family formation and dissolution; changes in behavior and values). In M. Corijn \& C. Van Peer (eds.). Gezinstransities in Vlaanderen (Family transitions in Flanders). Brussel:

Studiedienst van de Vlaamse Regering, SVR-studie 2, 109-134.

Crosbie-Burnett, M. (1989). Impact of custody arrangement and family structure on remarriage. Journal of Divorce, 13(1), 1-16.

Defever, C. \& Mortelmans, D. (2011). De socio-economische positie van vrouwen en mannen na de transities echtscheiding en verweduwing. Een longitudinale studie op de Kruispuntbank Sociale Zekerheid. Steunpunt Gelijkekansenbeleid.

De Graaf, P. M. \& Kalmijn, M. (2003). Alternative routes in the remarriage market: Competing-risk analyses of union formation after divorce. Social Forces, 81(4): 1459-1498.

Dykstra, P. A. \& Poortman, A. (2010). Economic resources and remaining single: Trends over time. European Sociological Review, 26(3), 277-290.

Eurostat (2012). Statistics [electronic resource]. Luxembourg: Eurostat. http://epp.eurostat.ec.europa.eu/portal/page/portal/population/introduction

Fokkema, T. (2001). Forse inkomensdaling voor vrouwen na echtscheiding en vroege verweduwing: Bieden hertrouw en werk uitkomst? Bevolking en Gezin, 30(1), 5-29. 
Fokkema, T. \& Dykstra, P. A. (2002). Differences in depression between married and divorced women in the Netherlands: In search of an explanation. The Netherlands' Journal of Social Science Research, 38(1), 24-47.

Goldscheider, F. K. \& Sassler, S. (2006). Creating stepfamilies: Integrating children into the Study of Union Formation. Journal of Marriage and Family, 68(2), 275-291.

Goldscheider, F. K. \& Waite, L. J. (1986). Sex differences in the entry into marriage. American Journal of Sociology, 92(1), 91-109.

Griffith, J. D., Koo, H. P. \& Suchindran, C. M. (1985). Childbearing and family in remarriage. Demography, 22(1), 73-88.

Gunnoe, M. L. \& Braver, S. L. (2001). The effects of joint legal custody on mothers, fathers, and children controlling for factors that predispose a sole maternal versus joint legal award. Law and Human Behavior, 25(1), 25-43.

Halman, L., Sieben, I., \& van Zundert, M. (2011). Atlas of European values. Trends and traditions at the turn of the century. Tilburg: Tilburg University \& Brill

Henz, U. \& Thomson, E. (2005). Union stability and stepfamily fertility in Austria, Finland, France \& West Germany. European Journal of Population, 21, 3-29.

Ivanova, K., Kalmijn, M. \& Uunk, W. (2013). The effect of children on men's and women's chances of re-partnering in a European Context. European Journal of Population, 29, 417-444.

Jansen, M., Mortelmans D. \& Snoeckx L. (2009). Repartnering and (re)employment: strategies to cope with the economic consequences of partnership dissolution. Journal of Marriage and Family, 71(5), 1271-1293.

Jefferies, J., Berrington, A. \& Diamond, I. (2000). Childbearing following marital dissolution in Britain. European Journal of Population, 16(3), 193-210. 
Jeynes, W. H. (2006). The impact of parental remarriage on children. Marriage and Family Review, 40(4), 37-41.

Kalmijn, M. \& Gelissen, J. (2007). The Impact of recohabitation on fertility: Evidence from life history data in the Netherlands. Journal of Comparative Family Studies, 38(4), 555-573.

Koo, H. P., Suchindran, C. M. \& Griffith, J. D (1984). The effects of children on divorce and remarriage: A multivariate analysis of life table probabilities. Population Studies, 38(3), 451-471.

Lampard R. \& Peggs, K. (1999). Repartnering: The relevance of parenthood and gender to cohabitation and remarriage among the formerly married. British Journal of Sociology, 50(3), 443465.

Meggiolaro, S. \& Ongaro, F. (2008). Repartnering after marital dissolution: Does context play a role? Demographic Research, 19(5), 1913-1932.

Meggiolaro, S. \& F. Ongaro (2010). The implications of marital instability for a woman's fertility: Empirical evidence from Italy. Demographic Research, 23, 963-996.

Mortelmans, D., Pasteels, I., Van Bavel, J., Bracke, P., Matthijs, K. \& Van Peer, C. (2011). Divorce in Flanders. Data collection and code book. http://www.divorceinflanders.be.

Oppenheimer, V. K. (1988). A theory of marriage timing: Assortative mating under varying degrees of uncertainty. American Journal or Sociology, 94(3), 563-591.

Pasteels, I. Corijn, M. \& Mortelmans, D. (2012). Een nieuwe partner na een echtscheiding? Opleidingsverschillen bij mannen en vrouwen in Vlaanderen. Tijdschrift voor Sociologie, 33(3-4), $331-352$.

Pasteels, I., Mortelmans, D. \& Van Bavel, J. (2011). Steekproef en dataverzameling (Sample and data collection). In D. Mortelmans, I. Pasteels, P. Bracke, K. Matthijs, J. Van Bavel \& C. Van Peer (Eds.), Scheiding in Vlaanderen (Divorce in Flanders). Leuven: Acco, 27-64. 
Poortman, A. R. (2007). The first cut is the deepest? The role of the relationship career for union formation. European Sociological Review, 23(5), 585-598.

Sassler, S. (2010). Partnering across the life course: Sex, relationships, and mate selection. In: Journal of Marriage and Family, 72(3), 557-575.

Sodermans, A. K. (2013). Parenting apart together. Studies on joint physical custody arrangements in Flanders. KU Leuven: Centre for Sociological Research [PhD thesis].

Sodermans, A. K., Matthijs, K. \& Swicegood, G. (2013). Co-parenting over time: The incidence and characteristics of joint physical custody families in Flanders. Demographic Research, 28, 821848.

Sodermans, A. K., Vanassche, S. \& Matthijs, K. (2013). Post-divorce custody arrangements and binuclear family structures of Flemish adolescents. Demographic Research, 28, 421-432.

South, S. J. (1991). Sociodemographic differentials in mate selection preferences. Journal of Marriage and Family, 53(4), 928-940.

Stewart, S. D., Manning, W. D. \& Smock, P. J. (2003). Union formation among men in the U.S.: Does having prior children matter? Journal of Marriage and Family, 65(1), 90-104.

Sweeney, M. (1997). Remarriage of women and men after divorce. The role of socioeconomic prospects. Journal of Family Issues, 18(5), 479-502.

Sweeney, M. (2010). Remarriage and stepfamilies: Strategic sites for family scholarship in the $21^{\text {st }}$ century. Journal of Marriage and Family, 72(3), 667-684.

Teachman, J.D. \& Heckert, A. (1985). The impact of age and children on remarriage: Further evidence. Journal of Family Issues, 6(2), 185-203. 
Vikat, A., Thomson, E. \& Hoem, J. M. (1999). Stepfamily fertility in contemporary Sweden: The impact of childbearing before the current union. Population Studies, 53(2), 211-225.

Vikat, A., Thomson, E. \& Prskawetz, A. (2004). Childrearing responsibility and stepfamily fertility in Finland and Austria. European Journal of Population, 20(1), 1-21.

Wallerstein, J. S. \& Blakeslee, S. (1989). Second chances: Men, women, and children a decade after divorce. Ticknor and Fields, New York.

Wineberg, H. (1990). Childbearing after remarriage. Journal of Marriage and Family, 52(1), 31-38. 
Table 1 Summary of research literature on the effect of parenthood on union formation with a partner with or without children in terms of needs, attractiveness and opportunities

\begin{tabular}{|c|c|c|c|c|c|}
\hline & $\begin{array}{l}\text { Divorcees with no } \\
\text { children }\end{array}$ & $\begin{array}{l}\text { Divorcees with full- } \\
\text { time residential } \\
\text { children }\end{array}$ & $\begin{array}{l}\text { Divorcees with part- } \\
\text { time residential } \\
\text { children }\end{array}$ & $\begin{array}{l}\text { Divorcees with non- } \\
\text { residential children }\end{array}$ & $\begin{array}{l}\text { Divorcees with adult } \\
\text { children }\end{array}$ \\
\hline $\begin{array}{l}\text { N1. Their need for a } \\
\text { childless partner }\end{array}$ & $\begin{array}{l}\text { + fertility intentions } \\
+ \text { co-residence / social } \\
\text { support }\end{array}$ & $\begin{array}{l}\text { + financial support } \\
\text { - restraint towards } \\
\text { simple stepfamily }\end{array}$ & $\begin{array}{l}\text { + financial support } \\
+ \text { co-residence / social } \\
\text { support } \\
\text { - restraint towards } \\
\text { simple stepfamily }\end{array}$ & $\begin{array}{l}\text { + co-residence / social } \\
\text { support }\end{array}$ & $\begin{array}{l}\text { + co-residence / social } \\
\text { support }\end{array}$ \\
\hline $\begin{array}{l}\text { N2. Their need for a } \\
\text { partner with children }\end{array}$ & $\begin{array}{l}\text { + co-residence / social } \\
\text { support }\end{array}$ & $\begin{array}{l}\text { + support in } \\
\text { childrearing } \\
\text { - restraint towards } \\
\text { complex stepfamily }\end{array}$ & $\begin{array}{l}\text { + support in } \\
\text { childrearing } \\
\text { + co-residence / social } \\
\text { support } \\
\text { - restraint towards } \\
\text { complex stepfamily }\end{array}$ & $\begin{array}{l}\text { + co-residence / social } \\
\text { support }\end{array}$ & $\begin{array}{l}\text { + co-residence / social } \\
\text { support }\end{array}$ \\
\hline $\begin{array}{l}\text { A1. Their attractiveness } \\
\text { to childless partner }\end{array}$ & $\begin{array}{l}\text { + no stepfamily } \\
+ \text { fertility intentions } \\
\text { + exchange theory } \\
\text { + homogamy }\end{array}$ & $\begin{array}{l}\text { - residential } \\
\text { stepfamily } \\
\text { + good parent effect }\end{array}$ & $\begin{array}{l}\text { - part-time residential } \\
\text { stepfamily } \\
\text { + part-time no } \\
\text { residential stepfamily } \\
\text { + good parent effect }\end{array}$ & $\begin{array}{l}\text { - stepfamily } \\
\text { + no residential } \\
\text { stepfamily } \\
\text { + good parent effect }\end{array}$ & $\begin{array}{l}\text { - stepfamily } \\
\text { + no residential } \\
\text { stepfamily }\end{array}$ \\
\hline $\begin{array}{l}\text { A2. Their attractiveness } \\
\text { to partner with children }\end{array}$ & $\begin{array}{l}\text { - simple stepfamily } \\
\text { + financial support }\end{array}$ & $\begin{array}{l}\text { + exchange theory } \\
\text { + homogamy } \\
\text { + good parent effect } \\
\text { - complex stepfamily }\end{array}$ & $\begin{array}{l}\text { + exchange theory } \\
+ \text { homogamy } \\
\text { + good parent effect } \\
\text { - complex stepfamily }\end{array}$ & $\begin{array}{l}\text { + exchange theory } \\
\text { + homogamy } \\
\text { + good parent effect } \\
\text { - complex stepfamily }\end{array}$ & $\begin{array}{l}\text { + exchange theory } \\
\text { + homogamy } \\
\text { - complex stepfamily }\end{array}$ \\
\hline $\begin{array}{l}\text { O1. Their opportunities } \\
\text { to meet childless } \\
\text { partner }\end{array}$ & + social activities & $\begin{array}{l}\text { - limited social } \\
\text { activities }\end{array}$ & + social activities & + social activities & + social activities \\
\hline $\begin{array}{l}\text { O2. Their opportunities } \\
\text { to meet partner with } \\
\text { children }\end{array}$ & $\begin{array}{l}\text { - restricted access to } \\
\text { network other parents } \\
\text { (school, community ..) }\end{array}$ & $\begin{array}{l}\text { + network other } \\
\text { parents (school, } \\
\text { community ..) }\end{array}$ & $\begin{array}{l}\text { + network other } \\
\text { parents (school, } \\
\text { community ..) }\end{array}$ & $\begin{array}{l}\text { - restricted access to } \\
\text { network other parents } \\
\text { (school, community ..) }\end{array}$ & $\begin{array}{l}\text { - restricted access to } \\
\text { network other parents } \\
\text { (school, community ..) }\end{array}$ \\
\hline
\end{tabular}


Table 2 Summary of research literature on the effect of parenthood on childbearing in higher order unions

\begin{tabular}{|c|c|c|c|c|c|c|}
\hline & & $\begin{array}{l}\text { Divorcees with no } \\
\text { children }\end{array}$ & $\begin{array}{l}\text { Divorcees with full- } \\
\text { time residential } \\
\text { children }\end{array}$ & $\begin{array}{l}\text { Divorcees with part- } \\
\text { time residential } \\
\text { children }\end{array}$ & $\begin{array}{l}\text { Divorcees with } \\
\text { non-residential } \\
\text { children }\end{array}$ & $\begin{array}{l}\text { Divorcees with } \\
\text { adult children }\end{array}$ \\
\hline \multirow[t]{2}{*}{$\begin{array}{l}\text { P. Parenthood } \\
\text { hypothesis }\end{array}$} & $\begin{array}{l}\text { Childless } \\
\text { partner }\end{array}$ & $\begin{array}{l}+ \text { both partners } \\
\text { becoming a parent }\end{array}$ & $\begin{array}{l}\text { + partner becoming a } \\
\text { parent }\end{array}$ & $\begin{array}{l}\text { + partner becoming a } \\
\text { parent }\end{array}$ & $\begin{array}{l}\text { + partner becoming } \\
\text { a parent }\end{array}$ & $\begin{array}{l}\text { + partner becoming } \\
\text { a parent }\end{array}$ \\
\hline & $\begin{array}{l}\text { Partner with } \\
\text { children }\end{array}$ & $\begin{array}{l}+ \text { divorcee } \\
\text { becoming a parent }\end{array}$ & $\begin{array}{l}\text { - both partners are } \\
\text { parents at start of } \\
\text { union }\end{array}$ & $\begin{array}{l}\text { - both partners are } \\
\text { parents at start of } \\
\text { union }\end{array}$ & $\begin{array}{l}\text { - both partners are } \\
\text { parents at start of } \\
\text { union }\end{array}$ & $\begin{array}{l}\text { - both partners are } \\
\text { parents at start of } \\
\text { union }\end{array}$ \\
\hline \multirow[t]{2}{*}{$\begin{array}{l}\text { C. Commitment } \\
\text { hypotheses }\end{array}$} & $\begin{array}{l}\text { Childless } \\
\text { partner }\end{array}$ & $\begin{array}{l}\text { + common child } \\
\text { with partner }\end{array}$ & $\begin{array}{l}\text { + common child with } \\
\text { partner }\end{array}$ & $\begin{array}{l}\text { + common child with } \\
\text { partner }\end{array}$ & $\begin{array}{l}\text { + common child } \\
\text { with partner }\end{array}$ & $\begin{array}{l}\text { + common child } \\
\text { with partner }\end{array}$ \\
\hline & $\begin{array}{l}\text { Partner with } \\
\text { children }\end{array}$ & $\begin{array}{l}\text { + common child } \\
\text { with partner }\end{array}$ & $\begin{array}{l}\text { + common child with } \\
\text { partner }\end{array}$ & $\begin{array}{l}\text { + common child with } \\
\text { partner }\end{array}$ & $\begin{array}{l}\text { + common child } \\
\text { with partner }\end{array}$ & $\begin{array}{l}\text { + common child } \\
\text { with partner }\end{array}$ \\
\hline $\begin{array}{l}\text { S. Sibling } \\
\text { hypothesis }\end{array}$ & & / & $\begin{array}{l}\text { + sibling for single } \\
\text { child }\end{array}$ & $\begin{array}{l}\text { + sibling for single } \\
\text { child }\end{array}$ & $\begin{array}{l}\text { + sibling for single } \\
\text { child }\end{array}$ & $\begin{array}{l}\text { + sibling for single } \\
\text { child }\end{array}$ \\
\hline $\begin{array}{l}\text { R. Childrearing } \\
\text { responsibilities } \\
\text { hypothesis }\end{array}$ & & $/$ & $\begin{array}{l}\text { - childrearing } \\
\text { responsibilities } \\
+ \text { already a } \\
\text { (step)family } \\
\text { - complex stepfamily }\end{array}$ & $\begin{array}{l}\text { - childrearing } \\
\text { responsibilities } \\
+ \text { already a } \\
\text { (step)family } \\
\text { - Complex stepfamily }\end{array}$ & $\begin{array}{l}\text { + no childrearing } \\
\text { responsibilities } \\
\text { - family formation } \\
\text { + no residential } \\
\text { stepfamily }\end{array}$ & $\begin{array}{l}\text { + no childrearing } \\
\text { responsibilities } \\
\text { - family formation } \\
\text { + no residential } \\
\text { stepfamily }\end{array}$ \\
\hline
\end{tabular}

LEGEND: + = increasing likelihood of childbearing; - = decreasing likelihood of childbearing 
Table 3 Descriptives of independent variables for full research sample and subsample of men and women in first post-separation union

\begin{tabular}{|c|c|c|c|c|c|c|c|c|}
\hline & \multicolumn{4}{|c|}{ Full research sample } & \multicolumn{4}{|c|}{$\begin{array}{l}\text { Subsample in first post- } \\
\text { separation union }\end{array}$} \\
\hline & \multicolumn{2}{|c|}{$\begin{array}{c}\text { Men } \\
(\mathrm{N}=2077)\end{array}$} & \multicolumn{2}{|c|}{$\begin{array}{c}\text { Women } \\
(\mathrm{N}=2384)\end{array}$} & \multicolumn{2}{|c|}{$\begin{array}{c}\text { Men } \\
(\mathrm{N}=1238)\end{array}$} & \multicolumn{2}{|c|}{$\begin{array}{c}\text { Women } \\
(\mathrm{N}=1268)\end{array}$} \\
\hline & \multicolumn{2}{|c|}{ Mean (S.D.) } & \multicolumn{2}{|c|}{ Mean (S.D.) } & \multicolumn{2}{|c|}{ Mean (S.D.) } & \multicolumn{2}{|c|}{ Mean (S.D.) } \\
\hline Age youngest child at time of separation & \multicolumn{2}{|c|}{$8.5(6.1)$} & \multicolumn{2}{|c|}{$8.1(6.1)$} & \multicolumn{2}{|c|}{$8.0(6.0)$} & \multicolumn{2}{|c|}{$7.2(5.8)$} \\
\hline $\begin{array}{l}\text { Number of children in dissolved marriage } \\
\text { with at least one child }\end{array}$ & \multicolumn{2}{|c|}{$1.9(0.9)$} & \multicolumn{2}{|c|}{$1.9(0.9)$} & \multicolumn{2}{|c|}{$1.9(0.9)$} & \multicolumn{2}{|c|}{$1.8(0.8)$} \\
\hline \multirow[t]{2}{*}{ Year of separation } & \multicolumn{2}{|c|}{$1998(7.3)$} & \multicolumn{2}{|c|}{$1998(7.3)$} & \multicolumn{2}{|c|}{$1997(7.3)$} & \multicolumn{2}{|c|}{$1997(7.0)$} \\
\hline & $\mathrm{n}$ & & $\mathrm{n}$ & $\%$ & $\mathrm{n}$ & & $\mathrm{n}$ & $\%$ \\
\hline \multicolumn{9}{|l|}{$\begin{array}{l}\text { Parental status at time of separation / start } \\
\text { first union }\end{array}$} \\
\hline No children & 534 & 26.1 & 528 & 22.5 & 355 & 28.9 & 367 & 29.1 \\
\hline Full-time residential, minor child(ren) & 166 & 8.1 & 1064 & 45.4 & 71 & 5.8 & 464 & 36.8 \\
\hline Part-time residential, minor child(ren) & 398 & 19.5 & 370 & 15.8 & 216 & 17.6 & 189 & 15.0 \\
\hline Non-residential, minor child(ren) & 642 & 31.5 & 88 & 3.8 & 353 & 28.8 & 48 & 3.8 \\
\hline Other arrangement with minor child(ren) & 133 & 6.5 & 122 & 5.2 & 74 & 6.0 & 62 & 4.9 \\
\hline All children 18 years or older & 167 & 8.2 & 173 & 7.4 & 158 & 12.9 & 131 & 10.4 \\
\hline Incomplete or invalid information & \multicolumn{2}{|l|}{37} & \multicolumn{2}{|l|}{39} & 11 & & 7 & \\
\hline Age at time of separation / start first union & & & & & & & & \\
\hline Younger than 30 years & 386 & 18.6 & 710 & 29.8 & 149 & 12.0 & 314 & 24.8 \\
\hline 30-39 years & 1035 & 49.8 & 1126 & 47.2 & 622 & 50.3 & 637 & 50.2 \\
\hline 40 years and older & 656 & 31.6 & 548 & 23.0 & 467 & 37.7 & 317 & 25.0 \\
\hline Educational level & & & & & & & & \\
\hline Lower & 542 & 26.2 & 517 & 21.7 & 300 & 24.3 & 262 & 20,7 \\
\hline Average & 869 & 42.0 & 993 & 41.7 & 535 & 43.4 & 551 & 43,6 \\
\hline Higher & 660 & 31.8 & 869 & 36.5 & 398 & 32.3 & 451 & 35,7 \\
\hline Missing & 6 & & & 5 & 5 & & & \\
\hline Parental status new partner & & & & & & & & \\
\hline No children & & & & & 597 & 48.2 & 590 & 46.5 \\
\hline At least one child & & & & & 640 & 51.8 & 678 & 53.5 \\
\hline Parental status in new union & & & & & & & & \\
\hline Both partners $n$ children & & & & & 231 & 18.7 & 231 & 18.2 \\
\hline Only respondent has child(ren) & & & & & 366 & 29.6 & 359 & 28.3 \\
\hline Only partner has child(ren) & & & & & 125 & 10.1 & 136 & 10.7 \\
\hline Both partners having child(ren) & & & & & 516 & 41.7 & 542 & 42.7 \\
\hline Age new partner at start first union & & & & & & & & \\
\hline Younger than 30 years & & & & & 393 & 31.8 & 215 & 17,0 \\
\hline 30-39 years & & & & & 490 & 39.6 & 539 & 42,5 \\
\hline 40 years and older & & & & & 298 & 24.0 & 475 & 37,5 \\
\hline Incomplete or invalid information & & & & & 57 & 4.6 & 39 & 3,1 \\
\hline
\end{tabular}


Table 4 Odds-ratios from multinomial hazard models modelling the likelihood of union formation with a partner with or without children, by sex

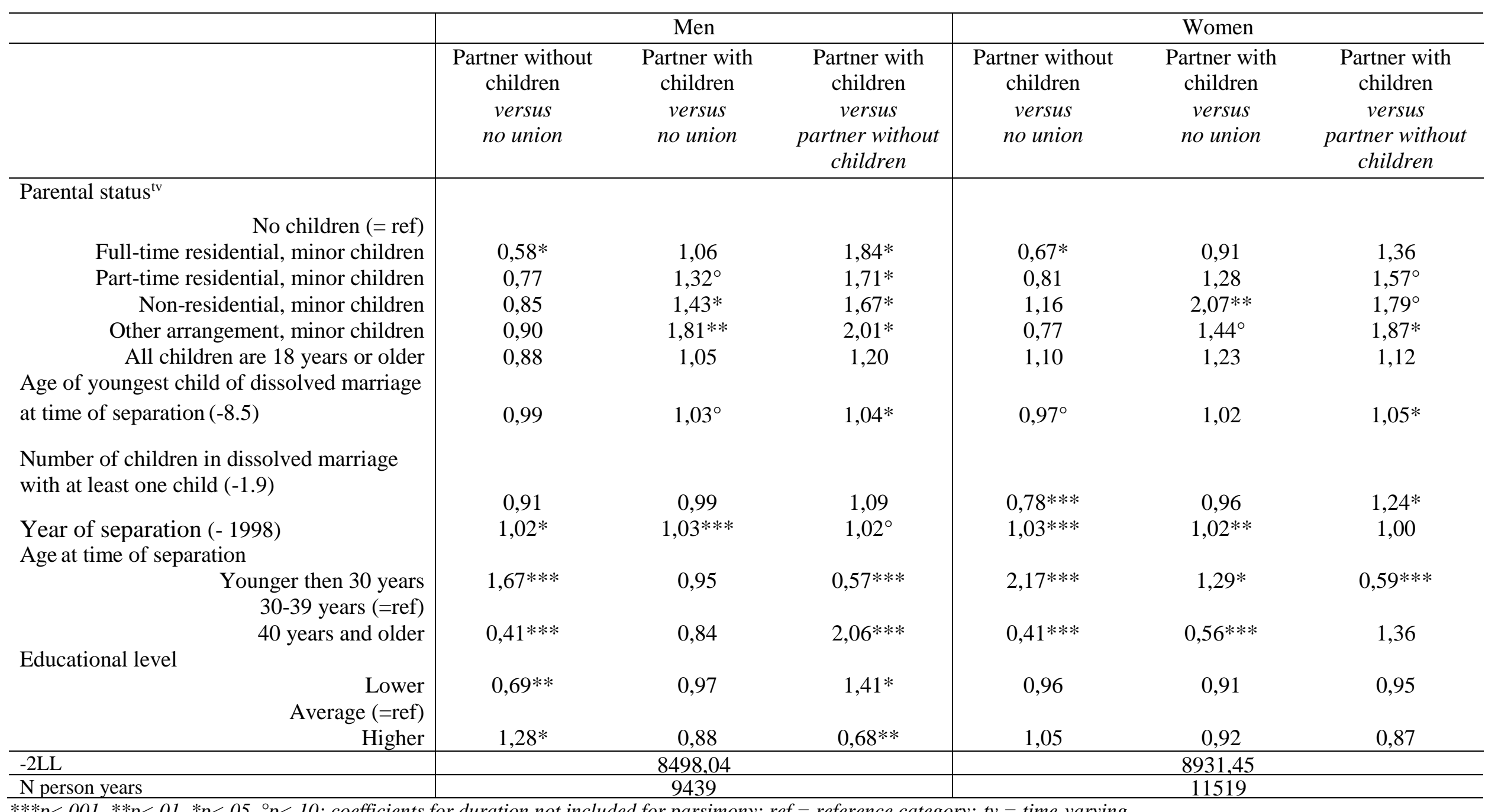

${ }_{* * *}^{*}<<.001 .{ }^{* *} p<.01 . * p<.05 .{ }^{\circ} p<.10 ;$ coefficients for duration not included for parsimony; ref = reference category; tv = time-varying 
Table 5 Odds-ratios from discrete-time event history analyses modelling the likelihood of a birth within the first union following separation, for men and women

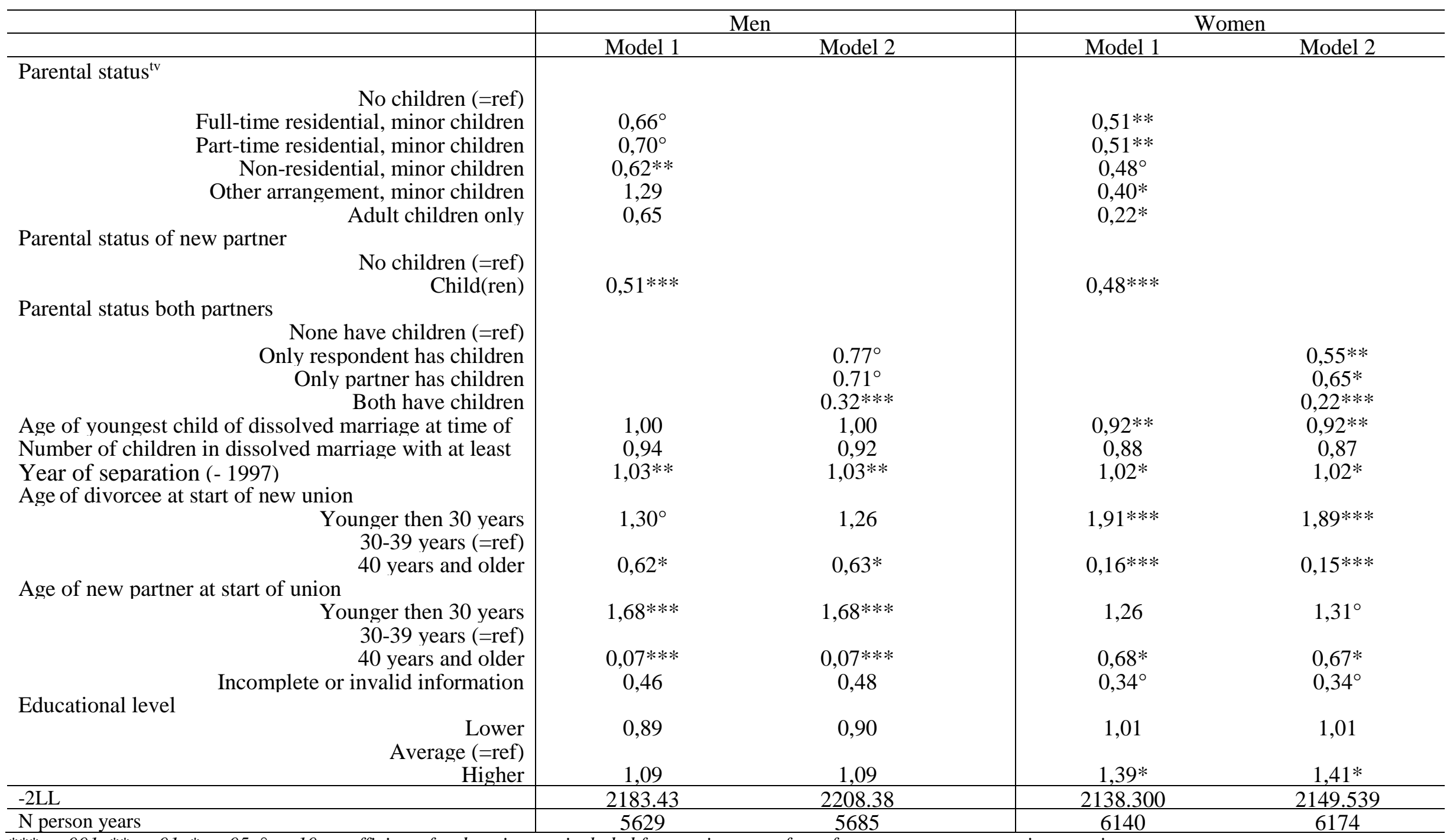

$* * * p<.001 . * * p<.01 . *^{*} p<.05 .{ }^{\circ} p<.10 ;$ coefficients for duration not included for parsimony; ref = reference category; tv = time-varying 